\title{
Occasional smoking among adults: evidence from the California Tobacco Survey
}

Nicola J Evans, Elizabeth Gilpin, John P Pierce, David M Burns, Ronald Borland, Michael Johnson, Dileep Bal

\begin{abstract}
Objective - To examine the incidence and correlates of occasional (non-daily) smoking among adults in California.

Design - Telephone survey.

Subjects-Population based sample of California residents $\geqslant 18$ years of age who had smoked at any time during the year before the survey interview $(n=$ 10599).

Main outcome measures - Cigarette consumption, recent attempts at stopping smoking, health and social attitudes to smoking, and respondents' workplace smoking policies; uptake smokers were defined as either age $\leqslant 25$ years or as smoking for $\leqslant 5$ years.
\end{abstract}

Results-The weighted percentage of current occasional smokers was $15 \cdot 4 \%$ (n $=1451$ ). Hispanic and black subjects were proportionately more likely to be occasional smokers than were white subjects. More occasional smokers than daily smokers worked where there was a smoking ban in their work area. Almost two thirds of occasional smokers were not in the process of uptake. Non-uptake occasional smokers tended to consume at a higher rate than uptake smokers, with one third smoking $\geqslant 60$ cigarettes a month. Occasional smokers seemed to differ from light, daily smokers in some health beliefs and social behaviours. Over $40 \%$ of occasional smokers had been either daily smokers or in a period of abstinence one year before the survey. Conclusions-Occasional smoking is often a transitional state associated with stopping smoking, although some adults might be long term occasional smokers. Further research on occasional smoking will be required to characterise more fully this smoking status. (Tobacco Control 1992; 1 : 169-75).

\section{Introduction}

A smoker has traditionally been described as a person who consumes cigarettes on a daily basis. Non-daily smoking is held to occur only during "uptake," a period of up to two years during which smokers begin consuming cigarettes irregularly before developing a nicotine dependence. ${ }^{1}$ By the end of the uptake period cigarette consumption is stable and smokers maintain similar blood concentrations of nicotine from day to day. ${ }^{2}$ If nicotine dependence is in part characterised by daily maintenance of blood nicotine concentrations, non-daily or occasional smoking should be rare among adult smokers no longer in the uptake phase. However, Shiffman et al have challenged the assumption that all smokers become dependent after lengthy exposure to cigarettes. ${ }^{3,4}$ In two laboratory studies Shiffman identified a group of tobacco "chippers" who habitually consumed five or fewer cigarettes a day without developing nicotine dependence, although blood samples of nicotine and assays of cotinine determined that all chippers were substantially exposed to nicotine. ${ }^{4}$ Two thirds of this sample of chippers abstained from smoking at least one day a week and thus may be described as occasional smokers.

To date, researchers have assumed a low prevalence of occasional smoking, based on surveys showing that only $5-10 \%$ of the smoking population consume five or fewer cigarettes a day. ${ }^{2}$ However, the prevalence of occasional smoking has never been measured because US surveys do not ask smokers whether they smoke every day. In this study we used data from the 1990 California Tobacco Survey to examine the incidence of occasional smoking among adults who were not in the uptake phase. As a preliminary investigation of occasional smoking we considered four questions. Firstly, to what extent do occasional smokers form a distinct subgroup that can be differentiated from daily smokers by sociodemographic characteristics and smoking patterns? Secondly, do occasional smokers resemble light, daily smokers in terms of health beliefs and social behaviours related to smoking? Thirdly, do environmental restrictions on smoking influence the prevalence of non-daily smoking? Fourthly, is occasional smoking a long term behaviour or a transient pattern of consumption adopted by smokers who are attempting to decrease their smoking over time?

\section{Methods}

The data in this study were gathered as part of the 1990 California Tobacco Survey, a population based telephone survey with telephone numbers dialled at random. Up to five attempts were made to reach each telephone number selected. In each identified household an adult received a screener questionnaire to list all household members and to collect basic demographic information, including smoking status. Of telephone numbers identified as households, $78 \%$ resulted in completed screener 
questionnaires. Next, indepth questionnaires were administered to adults ( $\geqslant 18$ years of age) in the household who currently smoked or had stopped smoking in the previous five years. A random subsample of $28 \%$ of non-smokers (never smokers, or ex-smokers who had not smoked for five years) also received this questionnaire. Of those selected for the extended questionnaires, $75 \%$ completed interviews. All interviews were conducted via a computer assisted telephone interview (CATI) system. Respondents could be interviewed in Spanish if they preferred. The sampling probabilities were used as part of the design effect to develop an initial weighting to provide population estimates. Poststratification weighting ensured that the sample was representative for age, sex, country or region, education, and race or ethnicity.

"Occasional" smokers met three criteria: they had smoked $\geqslant 100$ cigarettes, they smoked "some days" rather than "every day," and they had smoked $\leqslant 25$ days during the previous month. All ever smokers were asked about their smoking behaviour one year before the survey interview and their habitual consumption levels. The number and length of any attempts to stop smoking during the previous year were also recorded. Our study population comprised all those who had smoked at any point during the past year $(\mathbf{n}=$ 10599).

All participants in the survey who worked outside the home were asked three questions about smoking policies at their workplace. The answers to these questions were used to classify indoor workplaces into either work area ban (smoking prohibited in all public and work

Table 1 Distribution of demographic characteristics within smoking status group of all adults who had smoked during the previous year. Values are weighted percentages ( $95 \%$ confidence intervals)

\begin{tabular}{|c|c|c|c|}
\hline \multirow[b]{2}{*}{$\begin{array}{l}n^{\star} \\
\%\end{array}$} & \multicolumn{3}{|c|}{ Current smoking status $\star$} \\
\hline & $\begin{array}{l}\text { Daily } \\
7998 \\
73 \cdot 1\end{array}$ & $\begin{array}{c}\text { Occasional } \\
1451 \\
15.4\end{array}$ & $\begin{array}{c}\text { Abstinent } \\
1150 \\
11.5\end{array}$ \\
\hline $\begin{array}{l}\text { Sex: } \\
\text { Male } \\
\text { Female }\end{array}$ & $\begin{array}{l}55 \cdot 1(53 \cdot 4 \text { to } 56 \cdot 8) \\
44 \cdot 9(43 \cdot 2 \text { to } 46 \cdot 6)\end{array}$ & $\begin{array}{l}59 \cdot 9(55.7 \text { to } 64 \cdot 1) \\
40 \cdot 1(35.9 \text { to } 44.3)\end{array}$ & $\begin{array}{l}50.7(44.9 \text { to } 56.5) \\
49.3(43.5 \text { to } 55.1)\end{array}$ \\
\hline $\begin{array}{l}\text { Age (years): } \\
18-24 \\
25-29 \\
30-39 \\
40-49 \\
50-59 \\
\geqslant 60\end{array}$ & $\begin{array}{l}13.7(12.5 \text { to } 14.9) \\
13.3(12.5 \text { to } 14.1) \\
27.0(25.8 \text { to } 28.2) \\
20.7(19.5 \text { to } 21.9) \\
12.3(11.3 \text { to } 13.3) \\
13.1(12.2 \text { to } 14.0)\end{array}$ & $\begin{array}{c}25.5(20.2 \text { to } 30.8) \\
18.6(15.5 \text { to } 21.7) \\
25.1(21.4 \text { to } 28.8) \\
15.6(12.2 \text { to } 19.0) \\
8.9(5.7 \text { to } 12.1) \\
6.3(4.7 \text { to } 7.9)\end{array}$ & $\begin{array}{l}21.6(17.9 \text { to } 25.3) \\
16.0(12.6 \text { to } 19.4) \\
24.4(20.2 \text { to } 28.6) \\
15.4(11.6 \text { to } 19.2) \\
11.1(8.2 \text { to } 14.0) \\
11.5(8.6 \text { to } 14.4)\end{array}$ \\
\hline $\begin{array}{l}\text { Race: } \\
\text { Hispanic } \\
\text { White } \\
\text { Black } \\
\text { Asian } \\
\text { Other }\end{array}$ & $\begin{array}{c}14.5(12.6 \text { to } 16 \cdot 4) \\
69 \cdot 2(67.3 \text { to } 71 \cdot 1) \\
7.8(6 \cdot 7 \text { to } 8 \cdot 9) \\
5 \cdot 4(4 \cdot 1 \text { to } 6 \cdot 7) \\
3.2(2 \cdot 4 \text { to } 4 \cdot 0)\end{array}$ & $\begin{array}{c}35 \cdot 8(29 \cdot 4 \text { to } 42 \cdot 2) \\
42 \cdot 9(37 \cdot 6 \text { to } 48 \cdot 2) \\
12 \cdot 2(8 \cdot 8 \text { to } 15 \cdot 6) \\
6 \cdot 6(4 \cdot 1 \text { to } 9 \cdot 1) \\
2 \cdot 5(1 \cdot 3 \text { to } 3 \cdot 7)\end{array}$ & $\begin{array}{c}27.1(21.0 \text { to } 33.2) \\
60.0(53.8 \text { to } 66.2) \\
5.8(2 \cdot 1 \text { to } 9.5) \\
5.9(3.5 \text { to } 8.3) \\
1.2(0.4 \text { to } 2 \cdot 0)\end{array}$ \\
\hline $\begin{array}{l}\text { Education }( \\
<12 \\
12 \\
13-15 \\
\geqslant 16\end{array}$ & $\begin{array}{l}\text { f years): } \\
27 \cdot 9(26 \cdot 0 \text { to } 29 \cdot 8) \\
37 \cdot 5(36 \cdot 1 \text { to } 38 \cdot 9) \\
22 \cdot 8(21 \cdot 4 \text { to } 24 \cdot 2) \\
11 \cdot 8(10.8 \text { to } 12 \cdot 8)\end{array}$ & $\begin{array}{l}28.5(22.6 \text { to } 34.4) \\
33.0(28.4 \text { to } 37.6) \\
23.2(19.8 \text { to } 26.6) \\
15.3(12.5 \text { to } 18.1)\end{array}$ & $\begin{array}{l}28.2(22.3 \text { to } 34.1) \\
33.4(29.2 \text { to } 37.6) \\
24.0(19.7 \text { to } 28.3) \\
14.5(11.9 \text { to } 17.1)\end{array}$ \\
\hline $\begin{array}{l}\text { Family inco } \\
\text { Unknown } \\
\leqslant 10 \\
10-20 \\
20-30 \\
30-50 \\
50-75 \\
>75\end{array}$ & $\begin{array}{l}\text { housands of dollars }) \\
13.5(12.1 \text { to } 14.9) \\
12.2(10.8 \text { to } 13 \cdot 6) \\
14.7(13.3 \text { to } 16 \cdot 1) \\
16.9(15.6 \text { to } 18 \cdot 2) \\
21.5(20.0 \text { to } 23.0) \\
13.0(11.7 \text { to } 14.3) \\
8.2(7.2 \text { to } 9.2)\end{array}$ & $\begin{array}{l}13.4(9.9 \text { to } 16.9) \\
12.3(9.5 \text { to } 15 \cdot 1) \\
19.6(14.9 \text { to } 24.3) \\
12.9(10.2 \text { to } 15 \cdot 6) \\
19.8(16.2 \text { to } 23.4) \\
11.4(9.3 \text { to } 13.5) \\
10.6(8.7 \text { to } 12.5)\end{array}$ & $\begin{array}{l}10.4(7.3 \text { to } 13.5) \\
12.8(7.9 \text { to } 17.7) \\
13.8(10.3 \text { to } 17.3) \\
14.5(11.5 \text { to } 17.5) \\
22.7(19.1 \text { to } 26.3) \\
14.8(11.4 \text { to } 18.2) \\
11.1(7.5 \text { to } 14.7)\end{array}$ \\
\hline
\end{tabular}

$\star$ Unweighted sample size. areas or in the work area only) or no work area ban (no smoking policy, no smoking ban, or smoking allowed in some work areas or public areas).

\section{STATISTICAL ANALYSIS}

For all percentages in the figures and tables we have provided $95 \%$ confidence intervals derived using a variant of the jackknife procedure. ${ }^{5}$ We took 33 subsamples from the full survey file and computed sample weights according to the same procedure as for the full sample. Variance was estimated on the basis of the deviations of the subsample percentages and the percentage for the full sample. The variance was then used to compute a $95 \%$ confidence interval based on the critical value from the Student's $t$ distribution. $\chi^{2}$ statistics were computed using Satterthwaite's approximation, which is based on the subsamples (see above) and adjusts for the survey design. ${ }^{6,7}$

\section{Results}

WHO IS SMOKING OCCASIONALLY?

Table 1 shows current smoking status and demographic characteristics for all adults who had smoked during the previous year. Three groups were compared: daily smokers at the time of survey, abstinent smokers at the time of survey who were smoking the previous year, and occasional smokers at the time of survey. Occasional smokers composed $15.4 \%$ (weighted percentage) of this sample; fewer people had stopped smoking $(11.5 \%)$; most adult smokers $(73 \cdot 1 \%)$ smoked daily.

Occasional smokers were more likely to be male, as were daily smokers, whereas the sex distribution was almost equal among adults who had stopped smoking ( $\mathrm{p}<0.04$ overall). Education and family income levels were not significantly related to smoking status. The age distribution differed: overall, proportionately fewer older smokers were occasional smokers than were daily smokers $(p<0.0001)$. Nevertheless, the percentages of occasional smokers in the older age groups were higher than would be expected if occasional smoking were uniquely an uptake behaviour - for example, more than half of the occasional smokers were $\geqslant 30$ years old.

The racial or ethnic composition of the three smoking groups varied significantly. Proportionately, occasional smokers were more likely to be Hispanic or black ( $\mathrm{p}<0.0001$ ). Hispanic subjects accounted for $35.8 \%$ of all occasional smokers and only $14.5 \%$ of daily smokers. This pattern occurred to a lesser extent among Asians but was reversed for white subjects, with higher percentages of white adults in the stopped smoking or daily smoking category than in the occasional smoking category.

OCCASIONAL SMOKING AND UPTAKE BEHAVIOUR To identify uptake smokers within the occasional smoking group, we sorted occasional smokers by age and by the number of years they had been smoking. We hypothesised that as some occasional smokers become daily 
smokers the proportion of all smokers who are occasional would stabilise at a certain number of years after smoking was initiated-that is, at the end of the uptake phase. In our data the proportion of occasional smokers seemed to stabilise around three years after initiation, but we used five years as the criterion for a conservative estimate of the end of the uptake phase. Smokers were also categorised as uptake smokers if they were $\leqslant 25$ years old, on the basis of research showing that most adults begin smoking before they are $25 .{ }^{8}$

With these criteria, $38.3 \%$ of the occasional smokers were classified as uptake smokers. Hence nearly $62 \%$ of the occasional smokers in our sample were not in the uptake phase.

\section{CIGARETTE CONSUMPTION BY OCCASIONAL SMOKERS}

Figures 1 and 2 show the consumption patterns of occasional smokers, separating uptake smokers from other occasional smokers. Up-
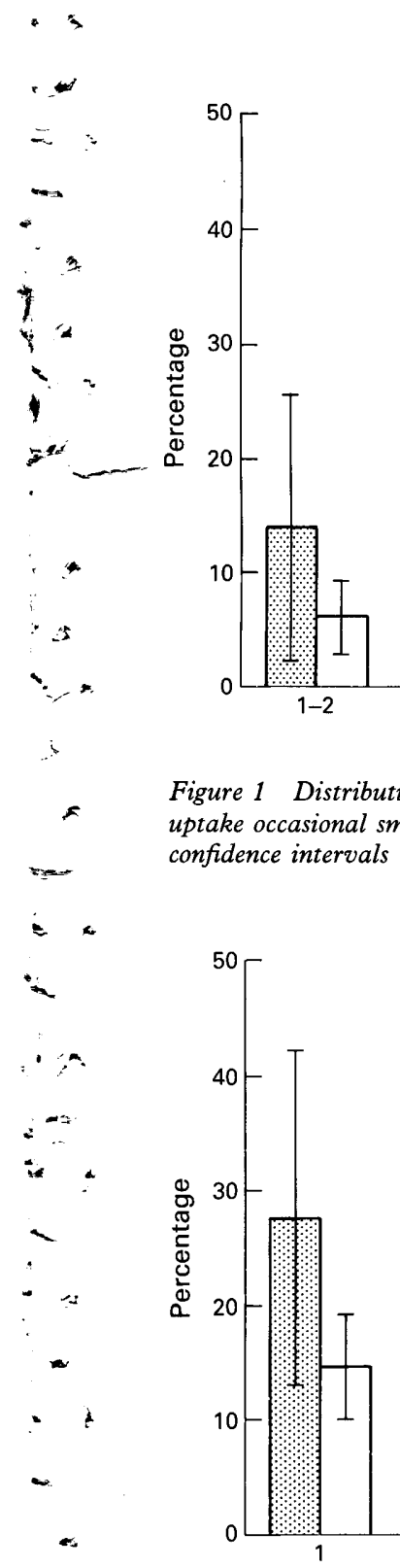

$\leftarrow$
Figure 1 Distribution of number of days when smoked in previous month among uptake occasional smokers and other occasional smokers. Vertical bars represent $95 \%$ confidence intervals
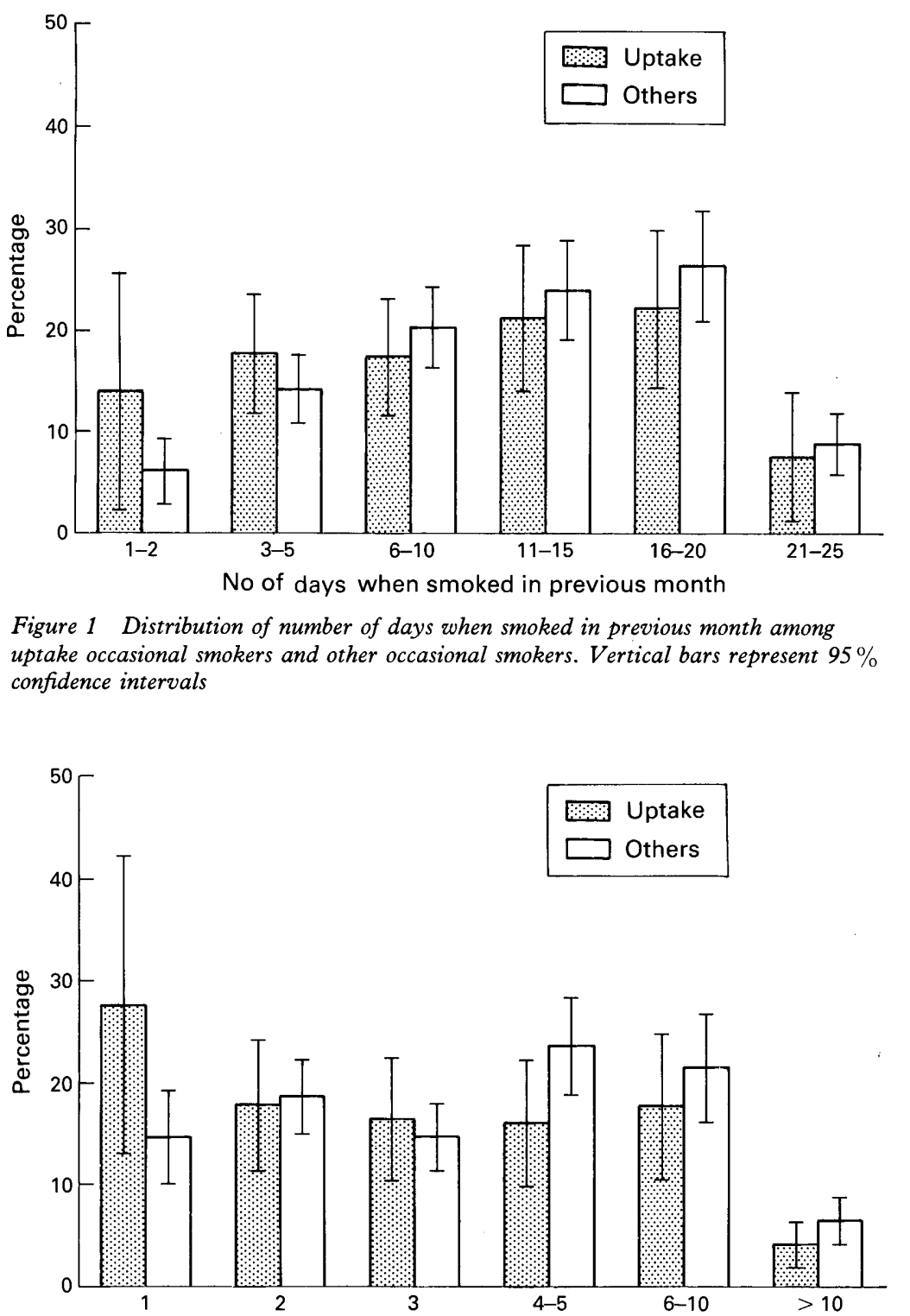

No of cigarettes/day on days smoked

Figure 2 Distribution of number of cigarettes smoked per day on the days smoked among uptake occasional smokers and other occasional smokers. Vertical bars represent $95 \%$ confidence intervals take smokers tended to smoke fewer days in the month (NS) and consumed fewer cigarettes on the days they did smoke $(p<0.06)$ than did non-uptake occasional smokers. For example, on the days that they smoked, $62 \%$ of uptake smokers and $48 \%$ of other occasional smokers smoked three or fewer cigarettes a day (figure 2). We also multiplied the number of cigarettes by days smoked: $38 \%$ of the non-uptake group and $26 \%$ of the uptake group smoked 60 or more cigarettes a month.

HEALTH BELIEFS AND SOCIAL BEHAVIOURS OF OCCASIONAL AND LIGHT SMOKERS

In view of the comparatively high rates of consumption among some non-uptake occasional smokers, we wondered whether they were distinct from light daily smokers. Table 2 compares the health beliefs and social behaviours of light and heavy occasional smokers ( $\geqslant 60$ and $<60$ cigarettes a month) with those of light and heavy daily smokers $(\leqslant 5$ and $>5$ cigarettes a day). Heavy occasional smokers differed from light daily smokers in their belief in tobacco's addictive power $(p<0.01)$, in their ratings of their own health $(p<0.05)$, and in their preference for non-smoking restaurant seating $(p<0.05)$. However, for two social behaviour items light daily smokers resembled occasional smokers more than other daily smokers-that is, in not smoking when they were the only smoker in a group and in asking other people not to smoke. For two health beliefs (personal addiction and preferring to smoke even if it shortens life time) the percentages increased across the four groups. Hence there was no consistent pattern of differences between heavy occasional smokers and other smoking groups across social or health belief items.

OCCASIONAL SMOKING AND WORKPLACE BANS

Among current smokers, occasional smokers were significantly more likely to report a work area smoking ban than were daily smokers $57.5 \%$ (95\% confidence interval $50.2 \%$ to $64.8 \%)$ v $47.3 \%(44.6 \%$ to $50.0 \%)$, respectively; $p>0.01)$. These percentages were virtually unaltered when uptake smokers were excluded.

MAINTENANCE OF OCCASIONAL SMOKING We studied the maintenance of occasional smoking over time among non-uptake smokers. Table 3 presents the current smoking status and the self reported status one year previously for all adults who had smoked during the previous year. Of current occasional smokers, $58.8 \%$ reported that they had also been smoking occasionally in the previous year. Approximately $41 \%$ of current occasional smokers had changed their status: $20.4 \%$ had been daily smokers and $20.8 \%$ were abstinent in the previous year. Many respondents reported a period of occasional smoking before stopping: $24 \%$ of those who were abstinent at the time of survey had been 
Table 2 Health beliefs and social attitudes of non-uptake occasional and daily smokers. Values are percentages of respondents agreeing, with $95 \%$ confidence intervals in parentheses

\begin{tabular}{|c|c|c|c|c|}
\hline \multirow[b]{2}{*}{$\begin{array}{l}n^{\star} \\
\% \dagger\end{array}$} & \multicolumn{2}{|c|}{ Occasional } & \multicolumn{2}{|c|}{ Daily } \\
\hline & $\begin{array}{l}<60 \text { cigarettes/ } \\
\text { month } \\
572 \\
7 \cdot 4\end{array}$ & $\begin{array}{l}\geqslant 60 \text { cigarettes } / \\
\text { month } \\
348 \\
4 \cdot 0\end{array}$ & $\begin{array}{l}\leqslant 5 \text { cigarettes/ } \\
\text { day } \\
559 \\
7 \cdot 8\end{array}$ & $\begin{array}{l}>5 \text { cigarettes/ } \\
\text { day } \\
7439 \\
83 \cdot 4\end{array}$ \\
\hline $\begin{array}{l}\text { Tobacco is not as addictive as other } \\
\text { drugs such as heroin or cocaine } \neq\end{array}$ & $28 \cdot 4(21 \cdot 0$ to $35 \cdot 8)$ & $23.7(17.5$ to 29.9$) 9$ & $37 \cdot 3(30 \cdot 1$ to $44 \cdot 5)$ & $23 \cdot 6(22 \cdot 1$ to $25 \cdot 1)$ \\
\hline $\begin{array}{l}\text { I believe that I am addicted to } \\
\text { cigarettes } \ddagger\end{array}$ & $39.9(33.0$ to 46.8$)$ & $62.0(52.6$ to $71 \cdot 4)$ & $69.7(64.5$ to 74.9$)$ & $88.2(87.0$ to 89.4$)$ \\
\hline $\begin{array}{l}\text { My smoking is harming my own } \\
\text { health }\end{array}$ & $81 \cdot 4(76 \cdot 5$ to $86 \cdot 3)$ & $87.5(82.4$ to 92.6$)$ & $85.0(81.4$ to 88.6$)$ & $85.8(84.2$ to 87.4$)$ \\
\hline $\begin{array}{l}\text { I prefer to smoke even if it means I } \\
\text { won't live as long } \neq\end{array}$ & $27 \cdot 2(21.5$ to 32.9$)$ & $35 \cdot 1(29 \cdot 0$ to $41 \cdot 2)$ & $39.2(33.0$ to 45.4$)$ & $50.7(48.9$ to 52.5$)$ \\
\hline $\begin{array}{l}\text { I believe I am in excellent or very } \\
\text { good health } \ddagger\end{array}$ & $62.7(53.5$ to 71.9$)$ & $62.9(54.7$ to $71 \cdot 1) \|$ & $48.5(41.4$ to 55.6$)$ & $52 \cdot 8(51 \cdot 1$ to $54 \cdot 5)$ \\
\hline $\begin{array}{l}\text { I rarely smoke when I am the only } \\
\text { smoker in the group } \ddagger\end{array}$ & $75 \cdot 1(70 \cdot 1$ to $80 \cdot 1)$ & $77.6(70.9$ to $84 \cdot 3)$ & $72 \cdot 2(65.4$ to 79.0$)$ & $65.6(63.9$ to 67.3$)$ \\
\hline $\begin{array}{l}\text { At least half the time at restaurants I } \\
\text { ask to sit in the non-smoking areał }\end{array}$ & $64.7(57.9$ to 71.5$)$ & $56 \cdot 7(48 \cdot 6$ to $64 \cdot 8) \|$ & $44.4(37.6$ to 51.2$)$ & $29 \cdot 1(27 \cdot 4$ to $30 \cdot 8)$ \\
\hline $\begin{array}{l}\text { I have asked someone not to smoke } \\
\text { in the past } 12 \text { months } \ddagger\end{array}$ & $58.6(51.6$ to $65 \cdot 6)$ & $52 \cdot 0(42 \cdot 7$ to $61 \cdot 3)$ & $52.5(45.9$ to $59 \cdot 1)$ & $39 \cdot 4(37.5$ to $41 \cdot 3)$ \\
\hline
\end{tabular}

in the past 12 months

* Unweighted sample size. Some respondents did not provide information on consumption.

$\dagger$ Weighted percentages.

$\ddagger \mathrm{p}<0.01$ overall $\chi^{2}$

$\mathrm{p}<0.05,9 \mathrm{p}<0.01$ for occasional smoking $\geqslant 60$ cigarettes/month $v$ daily smoking $\leqslant 5$ cigarettes/day. Pairwise $\chi^{2}$

performed only for these groups and only if overall $\chi^{2}$ significant.

occasional smokers in the previous year. Daily smokers were less likely to report a change in status: less than $12 \%$ of current daily smokers were not daily smokers in the previous year.

The "stability" shown by more than half of the occasional smokers may be deceptive. Table 4 shows the intentions to stop among smokers with the same smoking status as or a different smoking status from the previous year. Most of those whose status had changed had plans to stop smoking, and $81.9 \%$ of this group indicated an intention to stop at some point during the following six months. Of occasional smokers who had smoked occasionally a year ago, $69.0 \%$ also indicated an intention to stop during the following six months. Although the distribution of plans to quit varied significantly among groups ( $\mathrm{p}<0.0001$ ), the proportion of smokers who planned to stop was high across all three

Table 3 Current smoking behaviour in 1990 and smoking status one year previously. Values are percentages ( $95 \%$ confidence intervals)

\begin{tabular}{|c|c|c|c|}
\hline \multirow[b]{2}{*}{ Smoking status previously } & \multicolumn{3}{|c|}{ Current smoking status } \\
\hline & Daily & Occasional ${ }^{\star}$ & Abstinent \\
\hline $\begin{array}{l}\text { Daily } \\
\text { Occasional } \\
\text { Abstinent }\end{array}$ & $\begin{array}{c}88.4(87.3 \text { to } 89.5) \\
5.7(4.9 \text { to } 6.5) \\
5.9(5.2 \text { to } 6.6)\end{array}$ & $\begin{array}{l}20.4(16.6 \text { to } 24.2) \\
58.8(54.2 \text { to } 63.4) \\
20.8(17.3 \text { to } 24.3)\end{array}$ & $\begin{array}{l}76 \cdot 0(72 \cdot 2 \text { to } 79 \cdot 8) \\
24.0(20.2 \text { to } 27 \cdot 8) \\
\end{array}$ \\
\hline
\end{tabular}

* Excluding uptake occasional smokers.

Table 4 Plans to quit among smokers according to their current smoking behaviour in 1990 and their smoking status one year previously. Values are percentages (95\% confidence intervals)

\begin{tabular}{|c|c|c|c|}
\hline \multirow[b]{3}{*}{ Plans to quit } & \multicolumn{3}{|c|}{ Smoking behaviour currently and one year previously } \\
\hline & \multicolumn{2}{|c|}{ Same status ${ }^{\star}$} & \multirow[b]{2}{*}{ Different status $\dagger$} \\
\hline & Daily & Occasional & \\
\hline $\begin{array}{l}\text { None } \\
\text { In } 1 \text { month } \\
\text { In } 2-6 \text { months }\end{array}$ & $\begin{array}{l}39 \cdot 3(37.4 \text { to } 41 \cdot 2) \\
24 \cdot 1(22 \cdot 4 \text { to } 25 \cdot 8) \\
36 \cdot 7(35 \cdot 0 \text { to } 38 \cdot 4)\end{array}$ & $\begin{array}{l}31.1(25.5 \text { to } 36.7) \\
39.6(34.1 \text { to } 45 \cdot 1) \\
29.4(23.8 \text { to } 35.0)\end{array}$ & $\begin{array}{l}18.2(14.4 \text { to } 22.0) \\
45.4(38.6 \text { to } 52.2) \\
36.5(30.1 \text { to } 42.9)\end{array}$ \\
\hline
\end{tabular}

* Smokers who were smoking daily at time of survey and daily in previous year, or occasionally at time of survey and occasionally in previous year.

$\dagger$ Smokers who were smoking daily at time of survey and abstinent or smoking occasionally

in previous year, or who were occasional smokers at time of survey and daily smokers or abstinent in previous year. groups: even among daily smokers who were daily smokers last year, $60.8 \%$ reported plans to stop smoking. However, for many occasional smokers who had smoked occasionally in the previous year the plans were more imminent: $39.6 \%$ of this group intended to stop in the next month, whereas only $24 \cdot 1 \%$ of daily smokers who smoked daily the previous year planned to stop that soon.

Table 5 shows the distribution of current smokers who reported a period of abstinence of 30 or more days in the 12 months before the survey. Because some occasional smokers only smoke a few days each month, an abstinence of 30 days might represent their normal mode of consumption. To minimise this potential confounding factor, we restricted the occasional smoking group for this part of the analysis to those who smoked on more than five days a month.

Of current occasional smokers who were also occasional smokers one year previously, 35.1\% reported that they had abstained from smoking for 30 or more days during the year. This percentage is similar to that for the group of smokers whose status had changed: $34.0 \%$ of this group reported a period of abstinence lasting a month or more. Consistent with the plan to quit data, the group with the lowest proportion of one month abstainers $(17.7 \%$ ) comprised those who smoked daily at the time of survey and had also been smoking daily one year previously. Overall, the percentages who stopped smoking for 30 or more days differed significantly among the three groups $(p<$ $0 \cdot 0001$ ). Thus over a third of the apparently "stable" occasional smokers had interrupted their pattern of occasional smoking at least once during the past year in an attempt to stop smoking.

\section{Discussion}

We have presented evidence here that a significant percentage $(15.4 \%)$ of adult 
Table 5 Smokers who abstained 30 days or more, by current smoking behaviour and smoking status one year previously. Values are percentages (95\% confidence intervals)

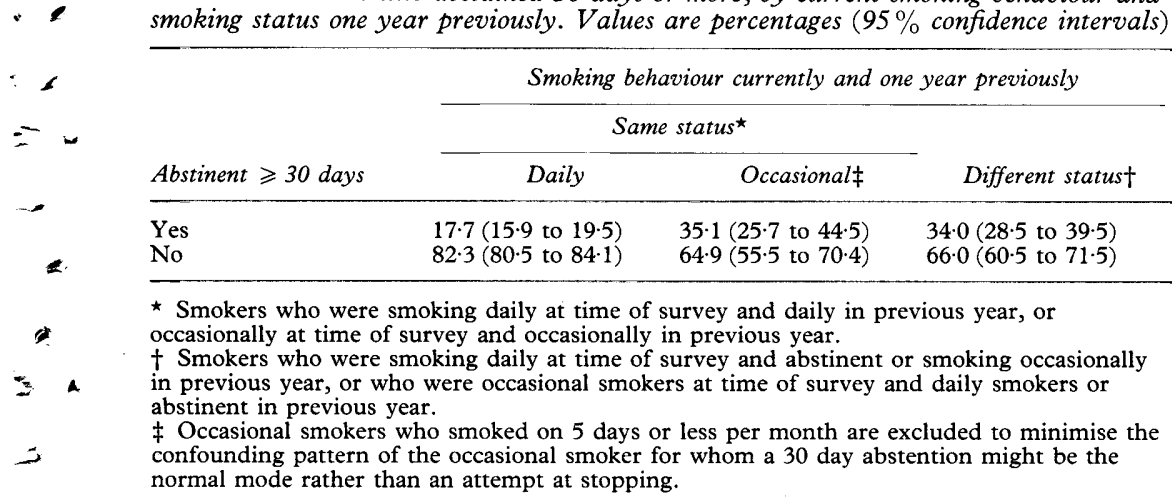

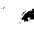

$-\cdot$

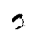

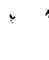

$:$

$\rightarrow 2$

$-$

1

is

.

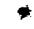

4

$\because \quad$

$\sim$

$\leftarrow$

-

$\div 4$

2

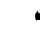

$-$

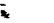

$\checkmark$

1

$\therefore$

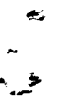

smokers in California do not smoke daily. Moreover, occasional smoking was not confined to new smokers. Nearly $62 \%$ of occasional smokers in our sample were no longer in the uptake phase. Non-uptake occasional smokers tended to smoke more than uptake smokers: over $38 \%$ of non-uptake occasional smokers consumed 60 or more cigarettes a month.

Past smoking behaviour, including attempts at stopping, showed that for many smokers occasional smoking is an intermediate behaviour preceding or following a change in smoking status. Of the non-uptake occasional smokers surveyed, $41 \%$ had not been occasional smokers one year previously, and of those who were occasional smokers both at the time of survey and one year previously, a third had attempted to stop at least once during the preceding year. Occasional smoking among non-uptake smokers may lead to stopping rather than to daily smoking: $24 \%$ of those who were abstinent at the time of the survey had been occasional smokers one year previously, but only $5.7 \%$ of the current daily smokers were occasional smokers one year previously. We cannot yet state conclusively whether occasional smoking is primarily a relapse or a quitting phenomenon. Between one year and the next smokers may fluctuate several times among different smoking patterns. More detailed smoking histories are required to pinpoint how the occasional smoking pattern fits into the smoking cycle.

We found some indications that occasional smokers form a distinct subgroup. Firstly, occasional smoking was overrepresented among Hispanic and black subjects; research is needed to assess whether these ethnic and racial differences have a cultural or a biological basis.

Secondly, occasional smoking was more prevalent among people who reported that smoking was prohibited in the work area at their place of employment. This result must be interpreted with caution. Previous research has found workplace smoking bans to be more successful in lowering cigarette consumption rates than in reducing smoking prevalence ${ }^{9-12}$; perhaps adults adjust their smoking behaviour to fit the new restrictions, and thus occasional smoking may be one way in which smokers respond to a workplace smoking ban. However, the link between occasional smoking and workplace bans is tentative because $(a)$ we do not know the effective dates of the bans and $(b)$ several factors may be implicated in occasional smoking, including activism by non-smokers at the workplace. In addition, occasional smokers were not asked about smoking consumption during work breaks or outside work hours. Considering these limitations, we propose more comprehensive evaluations of workplace smoking bans that include occasional smoking as a potential intervention outcome.

Thirdly, we observed some support for a distinction between occasional smokers and light, daily smokers. Though the research literature generally differentiates between light and heavy smokers, ${ }^{13,14}$ our results suggest this may not be the only useful distinction to make between smokers. For example, light daily smokers differed from heavy occasional smokers in their sense of the addictive nature of cigarettes. Conversely, on two items reflecting social behaviour light, daily smokers resembled occasional smokers more than they did other daily smokers. The varying alignments among smokers with different patterns of intake call for investigations of psychosocial factors which take into account both daily and non-daily smoking.

We argue here for a rethinking of the ways in which surveys assess smoking status. For example, in this survey respondents were asked if they had ever smoked 100 cigarettes, but they were not asked if they had ever smoked daily for a substantial period, a question used by some countries to classify someone as a smoker. The inclusion of this latter question in US surveys would eliminate the need to estimate the length of the uptake phase. As a caveat we note that some occasional smokers may be smokers who continued with the nondaily consumption patterns established during uptake.

Finally, occasional smoking may be of greater significance in developing countries than in developed countries. In this study family income was not related to occasional smoking, indicating that economic necessity probably does not force people to smoke occasionally in the United States. The case may be otherwise in countries where regular consumption of manufactured cigarettes represents a far larger portion of the family budget. Our results suggest a new agenda item for international surveys of smoking behaviour to increase the sensitivity of current measures to the full range of smoking practices and to bring survey questions more into line with the actual behaviour of smokers.

This study was supported by contract No 89-97872 from the California Department of Health Services, Tobacco Contro Section.

1 McKennel AC, Thomas RK. Adults' and adolescents' smoking habits and attitudes. London: Ministry of Health 1967

2 US Department of Health and Human Services. The health consequences of smoking: nicotine addiction. A report of the Surgeon General, 1988. Atlanta, Georgia: Centers of the Surgeon General, 1988. Atlanta, Georgia: Centers (DHHS Publication No (CDC) 88-8406.)

3 Shiffman S, Fischer LB, Zettler-Segal M, Benowitz NL. 
Nicotine exposure among nondependent smokers. Arch Gen Psychiatry 1990; 47: 333-6.

4 Shiffman S. Tobacco "chippers"-individual differences in tobacco dependence. Psychopharmacology 1989; 97: 539-47.

5 Efron B. The jackknife, the bootstrap and other resampling plans. Philadelphia: Society for Industrial and Applied Mathematics, 1982

6 Rao JNK, Scott AJ. The analysis of categorical data from complex sample surveys: chi-squared tests for goodness complex sample surveys. chi-squared tests for of fit and independence in two-way tables. fournal of the

7 Rao JNK, Scott AJ. On chi-squared tests for multiway contingency tables with cell proportions estimated from survey data. Annals of Statistics $1984 ; 12$ : 46-60.

8 US Department of Health and Human Services. Reducing the health consequences of smoking: 25 years of progress. A report of the Surgeon General, 1989. Atlanta, Georgia: Centers for Disease Control, Office on Smoking and Health, 1989. (DHHS Publication No (CDC) 89-8411.)
9 Borland R, Chapman S, Owen N, Hill D. Effects of workplace smoking bans on cigarette consumption. $A m \mathcal{F}$ Public Health 1990; 80: 178-80.

10 Beiner L, Abrams DB, Follick MJ, Dean L. A comparative evaluation of a restrictive smoking policy in a general hospital. Am $\mathcal{f}$ Public Health 1989; 79: a general

Petersen LR, Helgerson SD, Gibbons CM, Calhoun CR, Ciacco KH, Pitchford KC. Employee smoking behavior changes and attitudes following a restrictive policy on worksite smoking in a large company. Public Health Rep worksite smoking

12 Martin $M$, Fehrenbach A, Rosner R. Ban on smoking in Martin M, Fehrenbach A, Rosner R. Ban on

13 Schacter S. Nicotine regulation in heavy and light smokers. $\mathcal{f}$ Exp Psychol [Gen] 1977; 106: 5-12.

14 Killen JD, Fortmann SP, Telch MJ, Newman B. Are heavy smokers different from light smokers? $7 A M A$ $1988 ; 260: 1581-5$. 


\section{Translations of abstract}

$=$

$\sim$

$=$

,

$-$

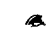

$-x$

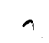

. 3

$-6$

$-2$

s:

2

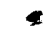

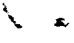

w.

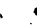

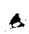

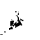

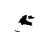

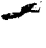

$=\infty$

a

$=$

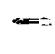

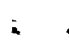

$\sim$
Tabagisme occasionnel chez les adultes: résultats de l'enquête californienne sur le tabac

Nicola J Evans et al

Résumé

Objectif: Examiner l'incidence et les facteurs liés au tabagisme occasionnel (non quotidien) chez les adultes en Californie.

Méthode: Enquête par téléphone.

Sujets: Echantillon de la population choisi parmi les résidents californiens âgés de plus de 18 ans qui on fumé dans l'année précédent l'entretien pour l'enquête ( $\mathrm{n}=10599$ ).

Base d'évaluation: Consommation de cigarettes, essais récents pour arrêter de fumer, santé et attitude sociale envers le tabagisme, et politique de restriction du tabagisme appliquée sur le lieu de travail de la personne interrogée; les fumeurs débutants étaient définis comme étant âgés de moins de 25 ans ou comme ayant fumé depuis moins de 5 ans.

Résultats: Le pourcentage pondéré de fumeurs ocasionnels actuels était de $15,4 \%(\mathrm{n}=1451)$. Les sujets hispaniques ou noirs avaient proportionnellement plus tendance á être des fumeurs occasionnels que les blancs. Plus de fumeurs occasionnels que de fumeurs réguliers travaillaient dans un endroit oú il était interdit de fumer. Près de deux tiers des fumeurs occasionnels n'étaient pas en train de devenir des fumeurs réguliers. Les fumeurs occasionnels qui n'étaient pas en train de devenir des fumeurs réguliers avaient tendance à consommer plus que les fumeurs qui commençaient à fumer, un tiers d'entre eux fumant plus de 60 cigarettes par mois. Les fumeurs occasionnels semblaient se différencier des petits fumeurs quotidiens en ce qui concerne certaines croyance sur la santé et le comportement social. Plus de $40 \%$ des fumeurs occasionnels on été fumeurs quotidiens ou ont eu une période d'abstinence un an avant l'enquête.

Conclusion: Le tabagisme occasionnel est souvent un état transitoire associé à la cessation du tabagisme, bien que certains adultes restent fumeurs occasionnels sur une longue période. D'autres recherches sur le tabagisme occasionnel sont nécessaires pour mieux caractériser ce type de tabagisme.
Tabaquismo ocasional entre los adultos: resultados de la encuesta sobre el uso del tabaco en California

Nicola J Evans et al

\section{Resumen}

Objetivo: Examinar la incidencia y correlaciones del tabaquismo ocasional (no cotidiano) entre los adultos de California.

Diseño: Encuesta telefónica.

Sujetos: Muestra de población basada en los residentes de California $>18$ años de edad que habían fumado en alguna ocasión durante el año anterior a la entrevista de la encuesta $(n=10599)$.

Principales evaluaciones obtenidas: Consumo de cigarrillos, intentos recientes por dejar el tabaquismo; actitudes sociales respecto de la salud y del tabaquismo y las normas sobre el tabaquismo en los lugares de trabajo de los entrevistados; por fumadores que adquirieron el tabaquismo se entendió a los $<$ de 25 años o a los que fumaban desde hace $<$ de 5 años.

Resultados: El porcentaje ponderado de los que en ese momento eran fumadores ocasionales fue 15,4\% $(n=1451)$. Proporcionalmente, resultó más probable que los sujetos hispanos y negros fuesen fumadores ocasionales que los blancos. En las áreas de trabajo en que estaba prohibido fumar el número de fumadores ocasionales era mayor que el de fumadores cotidianos.

Casi dos tercios de los fumadores ocasionales no se encontraba en proceso de adquirir el tabaquismo.

Los fumadores ocasionales que no habian adquirido el tabaquismo tendían a consumir cigarrillos a una tasa mayor que los fumadores que adquirieron el tabaquismo; un tercio de ellos fumaba $>60$ cigarrillos por mes. Los fumadores ocasionales diferian de los fumadores cotidianos que consumían pocos cigarrillos en algunas creencias sobre la salud y en ciertos comportamientos sociales. Más de $40 \%$ de los fumadores ocasionales habian sido fumadores cotidianos o habian pasado por un período de abstinencia un año antes de la encuesta.

Conclusiones: El tabaquismo ocasional es a menudo un estado de transición asociado con el cese de la adicción, aunque algunos adultos pueden seguir siendo fumadores ocasionales durante un largo plazo. Es preciso continuar las investigaciones sobre el tabaquismo ocasional para caracterizar con más precisión este estado del tabaquismo.

\section{成年人中的偶尔吸烟人群：加州烟草调查的例证 尼可拉，埃文斯等}

\section{目标：分析加州成年人中的偶尔吸烟率及其相关因素}

设计: 电话调查

对象： 10,599 名 18 岁以上在调查之前一年内曾经吸过烟的加州居民。 主要调查内容：卷烟消费、最近曾试图戒烟的努力、对吸烟的态度。工作单位对吸烟的政 策。

结果：偶尔吸烟率为 $15.4 \%$, 西班牙后裔和黑人中偶尔吸烟的比例要大大高于白人。在有戒 烟规定的工作单位偶尔吸烟率高于每日吸烟率, 偶尔吸烟者的社会行为和对健康的信念与轻 度吸烟者及每日吸烟者都有所不同。 $40 \%$ 以上的偶尔吸烟者在调查前都曾是每日吸烟者或曾 经吸烟者。

结论：尽管有一些成年人是长期的偶尔吸烟者, 但是偶尔吸烟经常是戒烟的一个过渡阶段。 对偶尔吸烟还需进一步研究, 才能进一步确定偶尔吸烟的特点。

(中国健康教育研究所烟草控制与疾病预防研究室 郑保义译) 